\section{НЕФОРМАЛЬНЫЕ И ФОРМАЛЬНЫЕ ИНСТИТУТЫ В КОНТЕКСТЕ ПОЛИТИЧЕСКОГО РЕЖИМА (НА ПРИМЕРЕ СССР)}

\begin{abstract}
Аннотация:
В статье обосновывается, что политический режим является важным объектом изучения не только с точки зрения политической науки, но также с позиции теории государства и права. Предложено использование методологического инструментария неоинституционального подхода для выявления особенностей формальных и неформальных институтов государства и характеристики взаимодействия политических акторов, $\boldsymbol{m}$. е. определения степени конкурентности режима. Дополнена характеристика политического режима категориальным аппаратом теории права (методами государственно-правового регулирования) $u$ государственного менеджмента (способами принуждения и убеждения). Утверждается, что правовые методы позволяют описать детальную картину политической и правовой реальности конкретных обществ. Сделан вывод о влиянии методов государственно-правового регулирования на политический режим. Институциональные параметры политического режима рассмотрены на примере Советского Союза.
\end{abstract}

Ключевые слова:

политический режим, неоинституционализм, институты, методы правового регулирования, авторитаризм, идеология, миф, СССР.

\section{INFORMAL AND FORMAL INSTITUTIONS IN THE CONTEXT OF THE POLITICAL REGIME (BY A CASE STUDY OF THE USSR)}

Summary:

The article proves that the political regime is an important issue from the viewpoint of political science along with the theory of state and law. It is proposed to apply the new institutional approach in order to reveal the features of the formal and informal institutions of the state and the characteristics of the interaction of political actors, determining the level of regime competitiveness. The description of the political regime is complemented by the categorical apparatus of law theory (methods of state and legal regulation) and state management (coercion and persuasion). It is argued that legal methods allow one to describe the political and legal reality of the societies in details. The author investigates the influence of the methods of state and legal regulation on the political regime. The institutional parameters of the political regime are examined by a case study of the Soviet Union.

Под политическим режимом (либо режимом) можно понимать «особый тип политической "игры", включающий в себя два основных элемента: 1) набор политических акторов ("игроков"), которые контролируют доступные им ресурсы и используют те или иные стратегии для достижения своих целей; 2) совокупность институтов, или "правил игры", которые накладывают ограничения и создают стимулы для действий политических акторов» [1, с. 82]. Будет уместным дополнить понятие «режим» третьим элементом: 3) государственные методы воздействия на общественные отношения. Таким образом, режим - это то, как правительство посредством социальных и правовых норм, устанавливающих правила поведения в обществе, влияет на граждан и оппозиционные политические объединения, используя в арсенале процессуальные правовые средства и методы фактического воздействия.

1. Акторами политического режима служат сегменты элит, которые влияют на принимаемые в обществе решения [2, р. 10]. В зависимости от того, какое количество игроков воздействует на политические события в стране, режимы нужно ранжировать по степени конкурентности аналогично способу, описанному в концепции «полиархии» Р. Даля. Например, в Советском Союзе коммунистическая партия выступала единственной политической силой в стране (вся оппозиция была фризически уничтожена), поэтому за весь период существования советский режим являлся неконкурентным.

2. Под институтами Д. Норт, сторонник неоинституционального подхода, понимал набор формальных и неформальных норм («правил игры») [3, с. 17-18]. Режиму важно, чтобы фрормальные институты (конституционные и правовые нормы) соотносились с неформальными (фактической деятельностью политических и правовых учреждений). Преобладание формальных институтов связывается с принципом верховенства права (rule of law), а неформальных - с господством произвола (arbitrary rule). 
Неформальные институты - это «принятые в обществе, обычно неписаные, правила, создаваемые, становящиеся известными и насаждаемые вне официально санкционированных каналов» [4, р. 192]. По Д. Норту, это обычаи, взаимные договоренности, убеждения, кодексы поведения, идеология, религия и т. д. [5, с. 64]. Это также личные связи, коррупция, клиентелизм, гражданское общество, кланы, мафии, традиционная культура и бюрократические нормы.

Ограничения, проявляющиеся в неформальных институтах, возникают как «средство координации устойчиво повторяющихся форм человеческого взаимодействия» [6, с. 61] и характеризуются следующими параметрами: складываются из формальных правил и превращаются в устойчивые институциональные ограничения вследствие многократного применения, хотя никогда не были частью таких правил; выбор может диктоваться социальными нормами, поскольку в обществе принято так поступать; отказ от богатства может произойти в пользу иных ценностей индивидуального характера. Например, идеология как неформальный институт была важна для всех сфрер жизни советского общества и государства. Так, Д. Норт пишет, что идеология имеет главное значение для человеческого выбора, поэтому значительные ресурсы тратятся на распространение кодексов поведения в социуме. «Институты меняют цену, которую мы платим за наши убеждения, и, следовательно, в решающей степени влияют на то, как мотивации, не связанные со стремлением к максимизации личной выгоды, определяют наш выбор» [7, с. 44]. Интересно, что как бы ни была сильна коммунистическая идеология вначале как средство формирования революционных кадров, она со временем теряла силу, когда происходила переориентация людей на индивидуализм, как это наблюдалось в СССР и Восточной Европе.

Формальные институты - это политические (и юридические) нормы, а также экономические правила и контракты. Помимо этого к ним относятся государственные учреждения, такие как суд, парламент, правительство, и «организационные правила», устанавливаемые корпорациями, политическими партиями и группами интересов [8, р. 31]. Функция формальных норм - повышение издержек тех фрорм обмена, которые препятствуют общественному развитию.

Политические правила устанавливают общественную иерархию, структуру принятия решений и закрепляются в конституциях (Конституции СССР 1936 г.), статутах (Декрете о власти) и законодательных постановлениях (Постановлении об образовании Совета труда и обороны и т. д.). Экономические правила определяют права собственности в фрорме статутов (ГК РСФСР 1922 г.), законодательных постановлений (декрете ЦИК СССР «О недрах земли и разработке их» и др.). Индивидуальные контракты содержат условия конкретного соглашения - это, в частности, договор купли-продажи (по ГК РСФСР 1922 г.).

Как отмечает Д.И. Гигаури, идеология, являясь неформальным институтом, находит выражение в нормативно закрепленной политической доктрине и доктринальных документах, что позволяет идеям быть оформленными юридически [9, с. 83]. В контексте истории СССР так происходило потому, что взаимоотношения между коммунистической партией и Советским государством определялись именно партийностью правового регулирования: высшие органы СССР выступали инструментом реализации решений политбюро [10, с. 174]. «Поэтому, - пишет С.В. Кодан, - совместные акты коммунистической партии и Советского государства служили средством законодательной легитимации государством идеологических и политических решений партии» [11, с. 39-53]. Таким образом, советская идеология посредством партийных документов становилась фрормальным институтом.

3. Под государственными методами воздействия на общество понимается совокупность средств и приемов как юридического (процессуального), так и внеправового (физического и когнитивного) характера, направленных на установление необходимых для политических элит социетальных порядков и властных практик. Существуют следующие виды государственного воздействия: методы государственно-правового регулирования и методы фрактического государственного регулирования.

Под методами государственно-правового регулирования понимают разновидность способов правового регулирования, представляющих собой совокупность юридических средств нормативного воздействия отраслей государственного права на общественные отношения, складывающиеся по поводу определения основ социума и государства, закрепления правового статуса человека и гражданина, установления системы государственной власти. Примеры того, как проявлялись указанные методы, можно найти в материалах Конституции СССР 1936 г.

Специфическими методами, используемыми только в конституционном праве, являются конституционное закрепление и общее установление. Первое способствует формированию общих конституционно-правовых отношений посредством норм-деклараций (например, «Статья 1. Союз Советских Социалистических Республик есть социалистическое государство рабочих и крестьян») [12, с. 285]. Второе содействует закреплению правовых норм с четким определением 
конституционно-правовых статусов гражданина и государства (в частности, «Статья 123. Равноправие граждан СССР независимо от их национальности и расы...») [13, с. 309].

Не стоит также забывать методы, которые применяются во всех отраслях права: императивный выражается в форме предписаний, запретов и ограничений; диспозитивный проявляется как дозволение. Они не всегда могут позволить дать точную характеристику режима, но благодаря им складывается детальная картина правовой реальности конкретных обществ, поскольку нельзя однозначно отрицать влияние правовых норм, даже минимальное при диктаторских режимах, на политические отношения.

Например, в нацистской Германии по устоявшейся правовой традиции законы действовали, однако большинство из них были неправовыми, т. е. нарушали права и свободы человека. В СССР, наоборот, одни законы не работали, а другие законы субъекты права выполняли с некоторыми перегибами. В связи с этим можно утверждать, что преобладание тех или иных методов государственно-правового регулирования хоть и косвенно, но влияет на политический режим.

Методы фрактического государственного регулирования - это совокупность мер государственного менеджмента, воздействующих на граждан в целях достижения определенных социально значимых результатов, проявляющихся в форме принуждения и убеждения. Методом принуждения являются политические репрессии - принудительные, карательные меры государства неправового характера против отдельных категорий людей по политическим мотивам для удержания власти, например Большой террор 1937-1938 гг. в СССР. Методы убеждения используют элиты для создания позитивного образа власти и государства, как правило, посредством трансляции политической идеологии и мифов в массы разными способами: «...церемонии, инсигнии, предания, фрормальности, собрание историй, которые они либо унаследовали от предыдущей власти, либо, в более революционных ситуациях, изобрели» [14, р. 124]. В частности, революционные дни как политические символы служили эфрфективным средством массовой пропаганды коммунистических идей, что в свою очередь поддерживало устойчивость процесса легитимации [15, с. 92].

Вопреки распространенной концепции «тоталитаризма», разработанной К. Фридрихом и 3. Бжезинским, для анализа режима в СССР применима типология представителя волюнтаристского подхода Б. Геддес, которая группирует недемократические режимы по типу акторов, принимающих решения: партия - в однопартийных режимах; армия - в военных; лидер единолично в персоналистских [16, р. 121]. Представляется, что Советский Союз - классический пример однопартийного авторитарного режима, в котором коммунистическая партия играла ведущую роль в генерации решений, оформляемых Советским государством согласно нормам права.

\section{Ссылки:}

1. Гельман В.Я. Из огня да в полымя? Динамика постсоветских режимов в сравнительной перспективе // Полис. 2007. № 2. C. 81-108.

2. Higley J., Gunther R. Elites and Democratic Consolidation in Latin America and Southern Europe. Cambridge (UK), 1992. P. 10.

3. Норт Д. Институты, институциональные изменения и функционирование экономики. М., 1997. С. 17-18.

4. Helmke G., Levitsky S. Informal Institutions and Democracy: Lessons from Latin America. Baltimore, 2006. P. 192.

5. Норт Д. Указ. соч. С. 64.

6. Там же. С. 61

7. Там же. C. 44.

8. Ellickson R.C. Order without Law: How Neighbors Settle Disputes. Harvard, 1991. P. 31.

9. Гигаури Д.И. Символические измерения политики идентичности // Теория и практика общественного развития. 2015. № 15. С. 83-87.

10. Кодан С.В. Партийно-государственные механизмы обеспечения и реализации идеологической бесколлизионности советского социалистического права (1917-1980-е гг.) // Юридическая техника. 2017. № 11. С. 172-177.

11. Кодан С.В. «Совет Народных Комиссаров и Центральный Комитет ВКП(б) постановляют...». Совместные нормативно-правовые акты коммунистической партии и Советского государства в системе источников советского права [Электронный ресурс] // Genesis: исторические исследования. 2016. № 1. С. 39-53. URL: http://e-notabene.ru/hr/article 17674.html (дата обращения: 10.08.2017).

12. Конституция (основной закон) Союза Советских Социалистических Республик : утв. Чрезвычайным VIII съездом Советов Союза ССР 5 дек. 1936 г. : с последующими изм. и доп. // Кукушкин Ю.С., Чистяков О.И. Очерк истории советской Конституции. М., 1987.

13. Там же. С. 309.

14. Geertz C. Centers, Kings and Charisma: Reflections on the Symbolics of Power // Local Knowledge: Further Essays in Interpretive Anthropology. N. Y., 1983. P. 124.

15. Гигаури Д.И. Политический мифф и ритуал как социокультурные основания символической политики // Вестник СанктПетербургского университета. Сер. 6. 2015. Вып. 3. С. 91-98.

16. Geddes B. What Do We Know about Democratization after Twenty Years? // Annual Review in Political Science. 1999. No. 2. P. 115-144. 


\section{References:}

Ellickson, RC 1991, Order without Law: How Neighbors Settle Disputes, Harvard, p. 31.

Geddes, B 1999, 'What Do We Know about Democratization after Twenty Years?', Annual Review in Political Science, no. 2 , pp. 115-144. https://doi.org/10.1146/annurev.polisci.2.1.115.

Geertz, C 1983, 'Centers, Kings and Charisma: Reflections on the Symbolics of Power', Local Knowledge: Further Essays in Interpretive Anthropology, New York, p. 124.

Gelman, VYa 2007, 'Out of the Frying Pan into the Fire? (Post-Soviet Regime Dynamics in Comparative Perspective)', Polis, no. 2, pp. 81-108. https://doi.org/10.17976/jpps/2007.02.06.

Gigauri, DI 2015a, 'Political myth and ritual as the social and cultural foundations of the symbolic policy', Vestnik SanktPeterburgskogo universiteta, Series 6, vol. 3, pp. 91-98, (in Russian).

Gigauri, DI 2015b, 'Symbolic dimensions of the identity policy', Teoriya i praktika obshchestvennogo razvitiya, no. 15, pp. 83-87, (in Russian).

Helmke, G \& Levitsky, S 2006, Informal Institutions and Democracy: Lessons from Latin America, Baltimore, p. 192. p. 10.

Higley, J \& Gunther, R 1992, Elites and Democratic Consolidation in Latin America and Southern Europe, Cambridge (UK),

Kodan, SV 2016, "'The Council of People's Commissars and the Central Committee of the All-Union Communist Party of Bolsheviks decide ...". Joint laws and regulations of the Communist Party and the Soviet state within the system of sources of Soviet law', Genesis: historical research, no. 1, pp. 39-53, viewed 10 August 2017, <http://e-notabene.ru/hr/article 17674.html>, https://doi.org/10.7256/2409-868x.2016.1.17674.

Kodan, SV 2017, 'Party mechanisms for ensuring and realizing the ideological lack of collision of Soviet socialist law (19171980)', Yuridicheskaya tekhnika, no. 11, pp. 172-177, (in Russian).

Kukushkin, YuS \& Chistyakov, OI 1987, 'Constitution (fundamental law) of the Union of Soviet Socialist Republics: approved by Extraordinary VIII Congress of Soviets of the USSR on December 05, 1936, revised and amended', Ocherk istorii sovetskoy Konstitutsii, Moscow, (in Russian).

North, D 1997, Institutions, institutional changes and economic performance, Moscow, pp. 17-18, (in Russian). 